\title{
Techno-economic Feasibility Analysis of Solar Photovoltaic System for Single Households in Peri-urban Areas Kumasi, Ghana
}

\author{
Bernard Aboagye $^{1,2}$, Samuel Gyamfi ${ }^{1}$, Julius Caesar Puoza ${ }^{2}$, Michael Obeng ${ }^{3}$ \\ ${ }^{1}$ Department of Energy and Environmental Engineering, University of Energy and Natural \\ Resources, Sunyani \\ ${ }^{2}$ Department of Mechanical Engineering, Sunyani Technical University, Sunyani \\ ${ }^{3}$ SMARTsolar Power Solutions, Sunyani \\ Ghana
}

\begin{abstract}
The rapid growth of new settlements at the outskirts of the cities in developing countries compels the residents of these areas to rely heavily on unreliable electricity supply and unsafe drinking water sources, and often pay higher prices than the approved utility rates. This paper used Simple Payback Analysis to assess the technical and economic feasibility of solar photovoltaic system for electricity supply without and with water supply system for single households in newly developing high-income peri-urban areas in developing countries using Kumasi, Ghana as case study. The study revealed that the $6 \mathrm{~kW}$ off-grid solar photovoltaic system designed for electricity supply cost US\$7950.00 with payback period of 15 years at US\$0.116/kWh. The addition of a 600 litres capacity water supply to the electricity supply system increased the cost to US\$10420.00 but reduced the payback period to 13 years at US\$0.116/kWh of electricity and US\$0.001154/L of water. Thus, the system meant to supply both electricity and water to the household would pay for itself before the project life of 25 years. Hence, solar PV system is technically and economically feasible for electricity and water supply for single households in newly developing high-income peri-urban areas in Ghana and other developing countries with similar socio-economic and climatic conditions.
\end{abstract}

Keywords: Techno-economic feasibility; solar photovoltaic system; electricity; water supply; periurban areas; Kumasi; Ghana.

\section{Introduction}

The importance of water and electricity to the world cannot be over emphasised because sustainable access to safe drinking water is essential for human health and survival, and electricity is the backbone of every economy. It was estimated that over 1.3 billion people worldwide did not have access to electricity [1] and 663 million people did not have access to potable water globally with 319 million living in sub-Saharan Africa and $80 \%$ of the people still without potable drinking water sources live in rural areas [2]. Electricity is used to purify and pump potable water and thus, the lack of access to potable water is worsened by lack of access to electricity especially in developing and under developed countries.

The rapid population growth, urbanisation, economic growth and increase in standards of living have led to rapid spatial expansion of cities, particularly cities in the developing countries. This has resulted in peri urban interface with three major internal spatial structures: the slums areas with illegal structures which accommodate the urban poor, the indigenous areas which consists of old buildings, and the newly developing peri-urban areas with new and modern houses which accommodate people who are mostly in the high-income bracket. The development of new settlements at the periphery of the cities has outpaced urban utility infrastructure capacity. The infrastructure therefore, struggle to keep pace with the numbers of people required to serve. Thus, there is increasing pressure worldwide on urban utility companies to expand their coverage and improve the quality of service [3]. However, due to rapid population growth, urbanisation and scarce financial resources, governments are unable to effectively provide electricity and water for all the urban population. Thus, inadequate electricity and water supply in the cities and towns remains a major problem in the developing world and the trend is unlikely to change in the foreseeable future unless prudent measures are put in place to increase the investment in these sectors to ensure provision of electricity and potable water in a reliable and sustainable manner. The residents of the newly 
developing peri-urban areas therefore, rely heavily on hand dug wells, rain harvesting and private mobile water tankers for their water supply needs and often pay higher prices than the approved rates [4]. They also depend mostly on portable generators, batteries, torchlights, candles and kerosene lamps as sources of power supply. These subject residents of new urban settlement areas in developing countries to the risk of using unsafe drinking water and unreliable power sources which poses serious problems to their health and productivity with increasing social vices in these areas and should therefore, be one of the topmost priorities of governments of developing countries.

Solar photovoltaic (PV) systems for electricity generation and water pumping systems have been implemented for communities in many countries in a sustainable manner and have been found to be cost effective [5, 6]. According to IRENA [1], some of the solar PV projects around the world are now regularly delivering electricity for just US\$ 0.08 per kilowatthour $(\mathrm{kWh})$ without financial support while that of fossil fuel power range from US\$ 0.045 to US\$ 0.14/kWh. Chandel et al. [7] reported that the payback period of some PV water pumping systems was 4-6 years and even only 2 to 3 years with expected lifetimes of over 25 years [8]. Therefore, solar PV systems for electricity generation and water pumping system which has been implemented around the globe and is an emerging technology in developing countries, has the potential to bring sustainable electricity and potable water to the unserved people living in the newly developing urban settlement areas in developing countries.

Several researches have been carried out to investigate the technical and economic feasibility of solar PV systems for either electricity supply $[9,10]$ or water pumping systems [11, 12] for rural and deprived communities. However, there is no available research on technical and economic feasibility analysis of solar PV systems for both electricity and water supply system for single households in peri-urban areas in the developing world. This study sought to conduct technical and economic feasibility of solar PV systems for electricity supply without water supply and with water supply systems for single households in newly developing peri-urban areas which accommodate people who are mostly in the high-income bracket using Simple Payback Analysis. Kumasi, the second largest city in Ghana, was used as case study. However, the results could be implemented in other developing countries with similar climatic conditions where electricity and water supply in peri-urban areas is a major challenge.

\section{Literature Review}

The techno-economic feasibility is the most importance mode of evaluating any system to ascertain how satisfactory a particular system would perform. This section presents a review of literature on the techno-economic evaluation of solar photovoltaic systems.

Bhakta and Mukherjee [13] conducted technoeconomic analysis on a $2.5 \mathrm{~kW} \mathrm{PV}$ power system to supply electricity for a single household in isolated island of India and reported that the initial capital cost of the system was $\$ 6773$ and supplied energy at US\$0.398 per $\mathrm{kWh}$. In a similar study, Kazem [14] performed techno-economic feasibility analysis of 1 MW photovoltaic grid connected system in Oman and found that the plant produced energy at around US\$0.2258 per kWh. The authors concluded that the PV technology was economically feasible and thus very promising area for investment. Imam [15] performed techno-economic feasibility evaluation for a $12.25 \mathrm{~kW}$ grid-connected rooftop PV system in Jeddah, Saudi Arabia and reported that the system produced energy at US\$0.0382 per kWh. Yaniktepe [16] carried out technoeconomic evaluation for a small-scale PV system with installed capacity of $1 \mathrm{MW}$ for electricity production in Osmaniye, Turkey and reported that the payback year about 6.27 years and 8.3 years using the simple payback period and net present value respectively.

Lal [17] carried out techno-economic analysis of solar PV water pumping system for rural areas of Indian State Rajasthan and reported that where there was $79 \%$ subsidy, the payback period was less than two years and concluded that solar PV water pumping system for rural areas is economically feasible only when the government provided above $60 \%$ subsidy. However, Singh [18] performed techno-economic feasibility study of solar water pumping for public facilities in Nigeria and reported that the facilities could save between $2-4$ times the amount used to purchase water from local water distributors if solar water pumping systems were used to supply water to meet their water needs. The author however, found that it was not economically sound to use small size solar water pumping system since it costs about twice the cost of purchased water from water distributors. Girma [11] performed technoeconomic analysis of photovoltaic pumping system for rural water supply in Ethiopia and found that that direct coupled PV water pumping system is technologically and economically feasible for rural water supply since the running cost is very low coupled with high reliability of the component and the entire system. In the solar water pumping advances and comparative economics analysis performed by [8], the authors reported that direct drive PVWP systems could deliver power for about US\$0.15 per kWh and the payback for solar PV 
water pumping system was only 2 to 3 years, with expected lifetimes of over 25 years.

Based on the literature it is evident that solar PV systems are technically and economically feasible for either water supply or electricity production for various locations. However, there is a study gap in technical and economic feasibility analysis of solar PV systems for both electricity and water supply system for single households in peri-urban areas in the developing countries where access to electricity and water supply is a major developmental challenge.

\section{Description of Study Area}

This section presents information about the area where the study was conducted including its location, population growth rate, electricity and water supply situation and monthly average solar radiation to justify the need for the study in this area.

Kumasi is located between Latitude $6.35^{\circ} \mathrm{N}$ and $6.40^{\circ} \mathrm{S}$ and Longitude $1.30^{\circ} \mathrm{W}$ and $1.35^{\circ} \mathrm{E}$. It is the second largest city in Ghana with population of about 2.0 million [19]. The city is growing a rapidly with an annual growth rate of $5.47 \%$ (Regional Statistical Office, Kumasi). Kumasi consists of about 90 suburbs due to its continuous growth and physical expansion. The electricity demand of Kumasi is one of the highest in Ghana due to urbanisation. The situation is not different in Kumasi with rapid growth of new settlements far ahead of infrastructural development. Although water production has increased over the years, residents in the City continues to experience frequent water shortages, mainly because the population growth has outstripped supply. Although the access to electricity in Ghana was over $87 \%$ for urban households [19] and urban water coverage stood at 76\% [20], there are disparities between the urban centres and the newly developing peri-urban areas. For instance, contrary to the $76 \%$ urban water coverage, $68 \%$ of houses in the new site area in Ayeduase in Kumasi lack supply of potable water [21]. Kumasi and Ghana as a whole have good potential of solar radiation throughout the year. The abundance of solar energy in Kumasi makes it promising for the installation of solar energy systems. The monthly averaged solar radiation for Kumasi obtained from NASA online data base of solar radiation [22] is given in Figure 1. The monthly averaged solar radiation for Kumasi is highest in February with radiation of $5.57 \mathrm{kWh} / \mathrm{m}^{2} /$ day and annual average solar radiation of $5.88 \mathrm{kWh} / \mathrm{m}^{2} /$ day. The monthly averaged solar radiation is low between June and September and the month of least in August with a radiation of $3.92 \mathrm{kWh} / \mathrm{m}^{2} /$ day. During these months, the amount of energy produced per day may be less than the demand per day and the system users are advised to use energy wisely.

\section{Methodology}

This section presents the specific procedures and techniques used for the technical design of the solar PV system including sizing and selection of various components of the system, and how the economic analysis was carried out in order to determine the feasibility of the system.

The electrical demand of the household was determined using the typical power ratings for electrical appliances [23]. A total daily load of $6 \mathrm{kWh}$ was obtained for the household. With this daily load, the battery storage was sized and Victron GEL OPzV batteries 2V, 600 Ah, C10 were selected. The solar PV module was sized and 8 polycrystalline modules of 320 W each (model: SPP-033202400) from BlueSolar were selected. The inverter and charge controller were sized and one pieces each of Phoenix Inverter 48/3000 inverter and Victron BlueSolar MPPT 150/45-Tr charge controllers were selected. The prices of the required components for the design of the system were collected from Victron Energy price list and solar PV shops in Kumasi. The warranty periods and replacement years for the components were obtained from the manufactures' websites. The economic analysis was carried out to determine the economic feasibility of the electricity supply system using Simple Payback Analysis with 25 years as the life time of the system.

The daily water consumption was determined using a typical household size of 5 people and per capita water consumption of $120 \mathrm{~L} /$ person/day which is usually taken as the design standard for high income group in urban areas in Ghana. This led to a total required volume of 600 litres of water per day. The total dynamic head was determined as $20 \mathrm{~m}$. Three days of autonomy was assumed and thus 1800 litres of water storage tank was required to cater for cloudy days or days without sunshine. The system was designed to pump $0.36 \mathrm{~m}^{3} / \mathrm{h}$ of water daily to the storage tank. With this flow rate and total dynamic head, a suitable solar pump (Lorentz Helical Rotor PS200 HR-07 Solar Submersible Pump System) was selected. The prices of the required components for the design of the water supply system were also collected and the economic analysis was carried out to determine the economic feasibility of the electricity and water supply system as described above.

\section{System Design}

This section Presents with the step-by step design of the electricity supply without and with water supply system. It deals with the calculations, sizing and selection of various components of the entire system. The payback analysis is also presented in this section. 


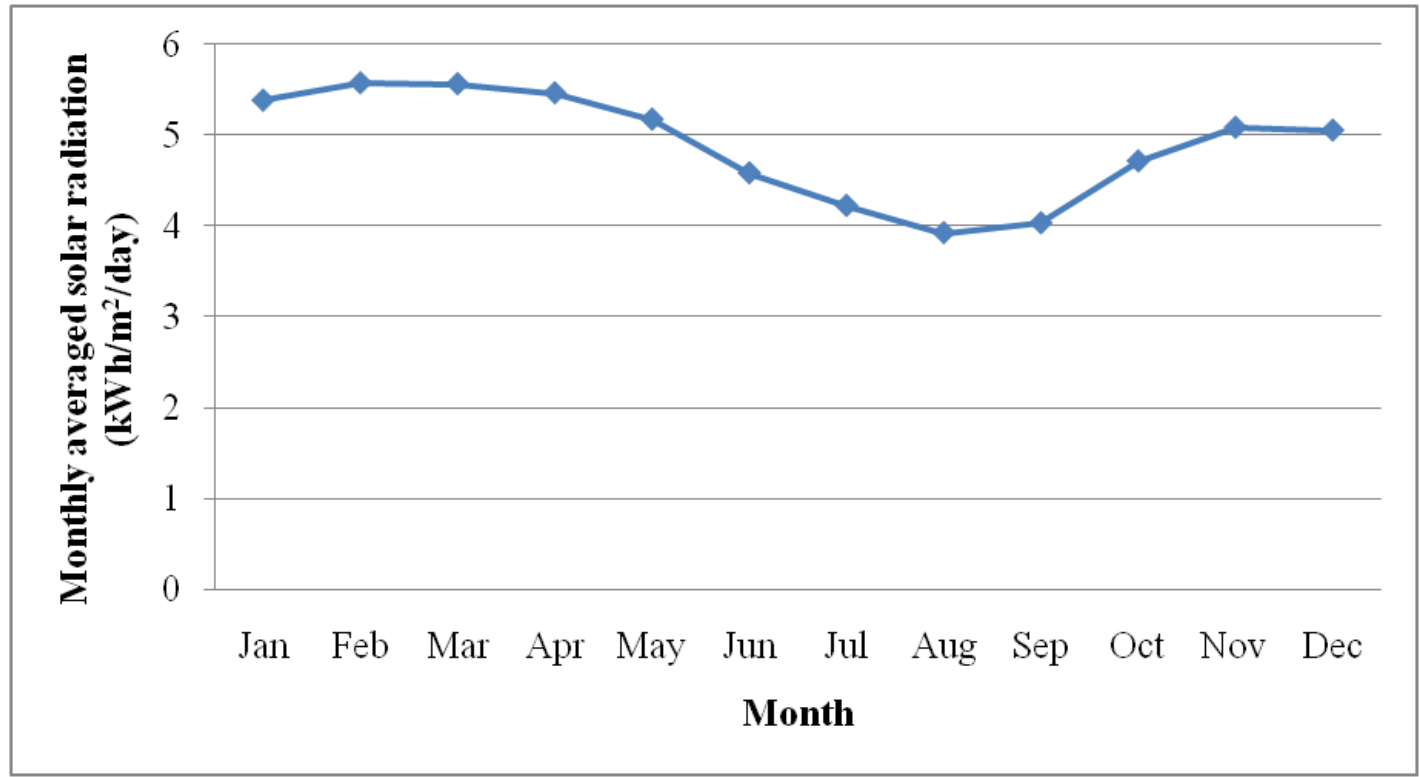

Figure 1. Monthly averaged solar irradiation [22]

\subsection{Electrical demand for electricity supply without water system}

The electrical demand of the household was estimated at $6 \mathrm{kWh}$ per day. This load was assumed to be constant throughout the year and the user would not use all the appliances at the same time and hence there would be enough energy throughout the year. The average daily load demand is calculated from Table 1.

\subsection{Sizing of the Battery}

The design of battery storage is based on the concept that it should have the ability to meet the peak demand of the household and still be able to supply power during a number of autonomous days; where the load demand is met solely by the storage system. The life of a battery is a function of its maximum depth of discharge (DOD), system voltage, battery efficiency and total daily demand. The system voltage, V was $48 \mathrm{~V}$ with maximum depth of discharge for the battery taken to be $80 \%$ and efficiency, $\eta$ of $85 \%$ [24].

Battery capacity $(\mathrm{Ah})=\frac{\text { Total daily demand in Wh }}{\mathrm{V} \times \mathrm{DOD} \times \eta}$
Battery capacity $=\frac{6 \times 1000}{48 \times 0.8 \times 0.85}=183.83 \mathrm{Ah}$

With three days of autonomy, battery capacity is adjusted to $183.83 \times 3=551.49 \mathrm{Ah}$

Standard Battery Capacity size of over $600 \mathrm{Ah}$ is required. Thus, Victron GEL OPzV batteries 2V, 600 $\mathrm{Ah}, \mathrm{C} 10$ is selected

Total number of batteries in series connection, $\mathrm{B}_{\mathrm{s}}$ is given by:

$B_{S}=\frac{\text { System Voltage }}{\text { Battery voltage }}=\frac{48}{2}=24$

Total number of batteries in parallel connection, $B_{p}$ is given by:

$B_{p}=\frac{\text { Sytem Capacity in } \mathrm{Ah}}{\text { Battery Capacity in Ah }}=\frac{551.49 \mathrm{Ah}}{600 \mathrm{Ah}}=0.9$

Total number of batteries in parallel connection $=1$

Total number of batteries needed, $B_{t}=B_{s} \times B_{p}$ $=24 \times 1=24$ 
Table 1. Average daily load demand

\begin{tabular}{lcccccccc}
\hline Appliance & Qty & $\begin{array}{c}\text { Load } \\
(\mathbf{W})\end{array}$ & $\begin{array}{c}\text { Total } \\
\text { load } \\
(\mathbf{k W})\end{array}$ & $\begin{array}{c}\text { Use/day } \\
\text { (hours) }\end{array}$ & Efficiency & $\begin{array}{c}\text { Daily } \\
\text { load } \\
\text { (kWh) }\end{array}$ & $\begin{array}{c}\text { Oversize } \\
\text { factor }\end{array}$ & $\begin{array}{c}\text { Adjusted } \\
\text { daily load } \\
\text { (kWh) }\end{array}$ \\
\hline Light bulb (Bedroom) & 4 & 11 & 0.044 & 2 & 1.00 & 0.09 & 1.10 & 0.10 \\
Light bulb (Toilet and & 2 & 11 & 0.022 & 1 & 1.00 & 0.02 & 1.10 & 0.02 \\
Bathroom) & & & & & & & & \\
Light bulb (Hall and & 3 & 11 & 0.033 & 5 & 1.00 & 0.17 & 1.10 & 0.18 \\
Corridor) & & & & & & & & \\
Outside light & 4 & 20 & 0.08 & 6 & 1.00 & 0.48 & 1.10 & 0.53 \\
Ceiling fan (Bedroom) & 4 & 50 & 0.2 & 1.5 & 1.20 & 0.36 & 1.10 & 0.40 \\
Ceiling fan (Hall) & 2 & 50 & 0.1 & 4 & 1.20 & 0.48 & 1.10 & 0.53 \\
Laptop & 2 & 75 & 0.15 & 2 & 1.00 & 0.30 & 1.10 & 0.33 \\
Inkjek printer & 1 & 100 & 0.1 & 0.25 & 1.00 & 0.03 & 1.10 & 0.03 \\
Refrigerator & 1 & 115 & 0.115 & 6 & 1.20 & 0.83 & 1.10 & 0.91 \\
TV & 1 & 100 & 0.1 & 4 & 1.00 & 0.40 & 1.10 & 0.44 \\
Radio & 1 & 10 & 0.01 & 4 & 1.00 & 0.04 & 1.10 & 0.04 \\
Mobile phone & 3 & 4 & 0.012 & 2 & 1.00 & 0.02 & 1.10 & 0.03 \\
Electric iron & 1 & 1000 & 1 & 0.5 & 1.20 & 0.60 & 1.10 & 0.66 \\
Washing machine & 1 & 500 & 0.5 & 0.5 & 1.20 & 0.30 & 1.10 & 0.33 \\
Microwave & 1 & 1000 & 1 & 0.25 & 1.20 & 0.30 & 1.10 & 0.33 \\
Blender & 1 & 300 & 0.3 & 0.25 & 1.20 & 0.09 & 1.10 & 0.10 \\
Electric Kettle & 1 & 2000 & 2 & 0.25 & 1.20 & 0.60 & 1.10 & 0.66 \\
Electric shaver & 1 & 15 & 0.015 & 0.25 & 1.20 & 0.00 & 1.10 & 0.00 \\
Total & & 5372 & 5.781 & & & 5.11 & & 5.62 \\
\hline & & & & & & & & \\
\hline
\end{tabular}

\subsection{Sizing of PV Modules}

The following parameters were used in sizing the PV array:

- Total daily energy in Watt-hours

- $\quad$ Average peak sun hour per day $=5$ hours

- $\quad$ DC-voltage of the system (VDC)

The system is expected to power all loads during peak hours. Thus, the modules should be able to deliver the required daily peak demand with the selected battery efficiency of $85 \%$.

Output power of array $=\frac{\text { Total Daily Demand in kWh }}{\text { Efficiency of Battery }}$

$=\frac{6}{0.85}=7.06 \mathrm{kWh}$

With the average peak sun hour of 5 hours per day, the total required output power of the array, $\mathrm{P}_{\mathrm{A}}$ is given by:
$P_{A}=\frac{\text { Output power of PV array }}{\text { Average sun hour per day }}$

$=\frac{7.06 \mathrm{kWh}}{5 \mathrm{~h}}=1.41 \mathrm{kWp}$

PV total output current from the array, $\mathrm{I}_{\mathrm{t}}$ is given by:

$$
\begin{aligned}
& I_{t}=\frac{\text { Total Output Power of Array }}{\text { System Voltage }} \\
& =\frac{1.41 \times 1000}{48}=29.37 \mathrm{~A}
\end{aligned}
$$

BlueSolar 320Watt 24Volt Polycrystalline Solar Module was selected.

The Selected module technical specifications are shown in Table 2. 
Table 2. Selected module technical specifications

\begin{tabular}{lc}
\hline Manufacturer & BlueSolar \\
\hline Model & SPP-033202400 \\
Cell technology & Polycrystalline \\
Peak power* - $\mathrm{P}_{\max }$ & $320 \mathrm{~W}$ \\
Max power current - $\mathrm{I}_{\mathrm{mp}}$ & $8.89 \mathrm{~A}$ \\
Max power voltage - $\mathrm{V}_{\mathrm{mp}}$ & $36 \mathrm{~V}$ \\
Short circuit current $-\mathrm{I}_{\mathrm{sc}}$ & $9.44 \mathrm{~A}$ \\
Open circuit current $-\mathrm{V}_{\mathrm{oc}}$ & $44.10 \mathrm{~V}$ \\
Number of cells per & 72 \\
module & \\
Dimensions & $1956 \times 992 \times 45 \mathrm{~mm}$ \\
Weight & $24.0 \mathrm{~kg}$ \\
Connectors & $\mathrm{MC} 4$ \\
\hline
\end{tabular}

*Standard Test Condition: $\mathrm{E}=1000 \mathrm{~W} / \mathrm{m}^{2}, \mathrm{~T}_{\mathrm{c}}=25^{\circ} \mathrm{C}$, $\mathrm{AM}=1.5$

The number of modules in series, $\mathrm{M}_{\mathrm{s}}$ is given by:

$M_{S}=\frac{\text { System voltage (VDC) }}{\text { Nominal Voltage of module }}=\frac{48}{24}=2$

The number of modules in parallel, $\mathrm{M}_{\mathrm{p}}$ is given by:

$M_{p}=\frac{I_{t}}{I_{m p} \text { of module } \mathrm{x} \text { Derating factor }}$

Assuming a derating factor of 0.8 , then,

$M_{p}=\frac{29.37}{8.89 \times 0.8}=4.13 \cong 4$

Total number of modules, $M_{t}=M_{s} \times M_{p}$ $=2 \times 4=8$

Peak rating of array $=M_{s} x P_{\text {max }}$ of module $=8 \times 320=2.56 \mathrm{kWp}$

\subsection{Tilt angle of solar panels}

Kumasi is located between Latitude $6.35^{\circ} \mathrm{N}$ and $6.40^{\circ} \mathrm{S}$ and Longitude $1.30^{\circ} \mathrm{W}$ and $1.35^{\circ} \mathrm{E}$. Thus, the optimal angle for solar panels is between $15-30^{\circ}$ facing south. In order to reduce dust accumulation and ensure effective cleaning by rainfall, tilt angle of $30^{\circ}$ facing south is chosen for this study.

\subsection{Sizing of the inverter}

PV modules produce direct current (DC) electrical power. However, most appliances are designed to operate on alternating current (AC) electrical power. Thus, an inverter is required to convert the DC electrical power from the PV modules to AC electrical power for electrical appliances to operate.

Sizing of inverters for PV systems are essential since the output of the PV systems depends on the size of the inverter. Thus, the rated capacity of the PV array must match the inverter capacity. The attainment of optimal PV/Inverter sizing depends on factors such local climate, PV surface orientation and inclination and inverter performance. Over sizing or under sizing the inverter increases costs. The optimum sizing ratio for a high efficiency inverter system for high and low insolation location should be within $1.1-1.2$ and $1.3-$ 1.4 respectively whereas for a low efficiency inverter system, the optimum sizing should be within $1.2-1.3$ and $1.4-1.5$ [25]. Based on this, array to inverter ratio (A/I) of 1.1 was used for this design.

DC rating of solar array $=$ number of modules $\mathrm{x}$ Peak power of each module $\left(\mathrm{P}_{\max }\right)$

DC rating of solar array, $\mathrm{DC}=M_{t} x P_{\max }$ of module $=8 \times 320=2560 \mathrm{~W}$

Maximum AC output of inverter $=\frac{\mathrm{DC}}{\mathrm{A} / \mathrm{I}}$

$=\frac{2560}{1.1}=2327.27 \mathrm{~W}$

Assume power factor of 0.8 , the rated power of the inverter in $\mathrm{kVA}$ is given by:

Power in $\mathrm{kVA}=\frac{\text { Power in } \mathrm{kW}}{\text { Power factor }}$ $=\frac{2.327 \mathrm{~kW}}{0.8}=2.91 \mathrm{kVA}$

Thus, one of Phoenix Inverter 48/3000 inverter is selected.

\subsection{Charge controller}

The primary function of a charge controller in a stand- alone PV system is to maintain the battery at highest possible state of charge while protecting it from overcharge by the array and from over discharge by the loads.

Total current through the controller, $\mathrm{I}_{\mathrm{c}}$ is given by: $I_{c}=I_{s c}$ of module $x M_{p} x$ Safety factor of 1.25 $=9.44 \times 4 \times 1.25=47.2 \mathrm{~A}$

Based on this current, Victron BlueSolar MPPT 150/45 controller was selected

Total number of controllers, $\mathrm{C}_{\mathrm{t}}$ required is given by: $C_{t}=\frac{I_{c}}{\text { Rated current of charge controller }}$

$=\frac{47.2}{45}=1.05$

One piece of Victron BlueSolar MPPT 150/45-Tr Controller is required. 


\subsection{Estimated cost of components for electricity supply without water system}

The estimated cost for the components used for the electricity supply without water system is shown in Table 3.

Table 3. Cost estimate of components

\begin{tabular}{lccc}
\hline Item/Description & Quantity & $\begin{array}{c}\text { Unit } \\
\text { Price } \\
\text { US\$ }\end{array}$ & $\begin{array}{c}\text { Total } \\
\text { US\$ }\end{array}$ \\
\hline $\begin{array}{l}\text { Energy generation } \\
\text { system }\end{array}$ & & & \\
$\begin{array}{l}\text { Victron GEL OPzV } \\
\text { battery 2V, 600 Ah, C 10 }\end{array}$ & 24 & 100 & 2400 \\
$\begin{array}{l}\text { BlueSolar 320Watt } \\
\text { 24Volt Polycrystalline }\end{array}$ & 8 & 300 & 2400 \\
$\begin{array}{l}\text { Solar Module } \\
\text { Battery cable 54mm², red }\end{array}$ & $3 \mathrm{~m}$ & 30 & 90 \\
$\begin{array}{l}\text { Battery cable 54mm², } \\
\text { black }\end{array}$ & $3 \mathrm{~m}$ & 30 & 90 \\
$\begin{array}{l}\text { DC fuse 200 A } \\
\text { Phoenix Inverter 48/3000 }\end{array}$ & 1 piece & 1245 & 1242 \\
$\begin{array}{l}\text { inverter } \\
\begin{array}{l}\text { Solar panel installation } \\
\text { profile }\end{array}\end{array}$ & 4 pieces & 52 & 208 \\
$\begin{array}{l}\text { Solar installation DC- } \\
\text { components (Panel }\end{array}$ & $100 \mathrm{~m}$ & 4 & 400 \\
$\begin{array}{l}\text { Cables) 6mm } \\
\text { Victron BlueSolar MPPT }\end{array}$ & 1 piece & 504 & 504 \\
$\begin{array}{l}\text { 150/45 Controller } \\
\text { Engineering and labour } \\
\text { cost }\end{array}$ & 1 & 600 & 600 \\
Total & & & 7950 \\
\hline
\end{tabular}

\subsection{Simple payback analysis for electricity supply without water system}

In order to accurately estimate the lifetime cost of the project, 25 years which is the warranty period of the solar PV modules was used as the project lifetime. Solar PV stand-alone systems have very minimal maintenance cost. The present prevailing industry rates for operation and maintenance $(\mathrm{O} \& \mathrm{M})$ cost is $10 \%$ of system cost. Therefore,

$\mathrm{O} \& \mathrm{M}$ cost of the system $=10 \%$ of US $\$ 7950=\mathrm{US} \$ 795$

The battery may be replaced 2 times in 25 years using the warranty period of 10 years. Therefore,

Battery replacement cost, $C_{B}=2 \times$ Initial cost of battery $=2 \times 2400=\mathrm{US} \$ 4800$

Total lifecycle cost of system, $\mathrm{T}_{\mathrm{E}}$ is given by:

$\mathrm{T}_{\mathrm{E}}=$ System cost $+\mathrm{O} \& \mathrm{M} \operatorname{cost}+\mathrm{C}_{\mathrm{B}}$

$=7950+795+4800=$ US $\$ 13545$
Estimated annual energy generated, $\mathrm{E}_{\mathrm{A}}$ is given by:

$\mathrm{E}_{\mathrm{A}}=$ Energy generated per day $\mathrm{x} 365$ days in a year

$=(2.56 \mathrm{~kW} \times 5 \mathrm{hrs}) \times 365=4672 \mathrm{kWh}$

Energy generated during the 25 years, $\mathrm{E}_{\mathrm{T}}$ is given by:

$\mathrm{E}_{\mathrm{T}}=\mathrm{E}_{\mathrm{A}} \times 25$ years

$=4672 \mathrm{kWh} \times 25=116800 \mathrm{kWh}$

Energy cost $(\mathrm{US} \$ / \mathrm{kWh})=\frac{T_{E}}{\mathrm{E}_{T}}$

$=\frac{\$ 13545}{116800}=\mathrm{US} \$ 0.116 / \mathrm{kWh}$

Net annual cash inflow, $\mathrm{N}_{\mathrm{E}}$ from the system is given by:

$\mathrm{N}_{\mathrm{E}}=\mathrm{E}_{\mathrm{A}} \times$ Energy cost

$=4672 \mathrm{kWh} \times \mathrm{US} \$ 0.116 / \mathrm{kWh}=\mathrm{US} \$ 541.95$

Simple Payback Period, SPP is given by:

SPP $=\frac{\text { (Total installed cost for electricity }- \text { Incentives) }}{N_{E}}$

$=\frac{7950-0}{541.95}=14.7$

Simple payback period $=15$ years

\subsection{Design of water pumping system}

The total vertical lift is determined from the water pumping system in Figure 2.

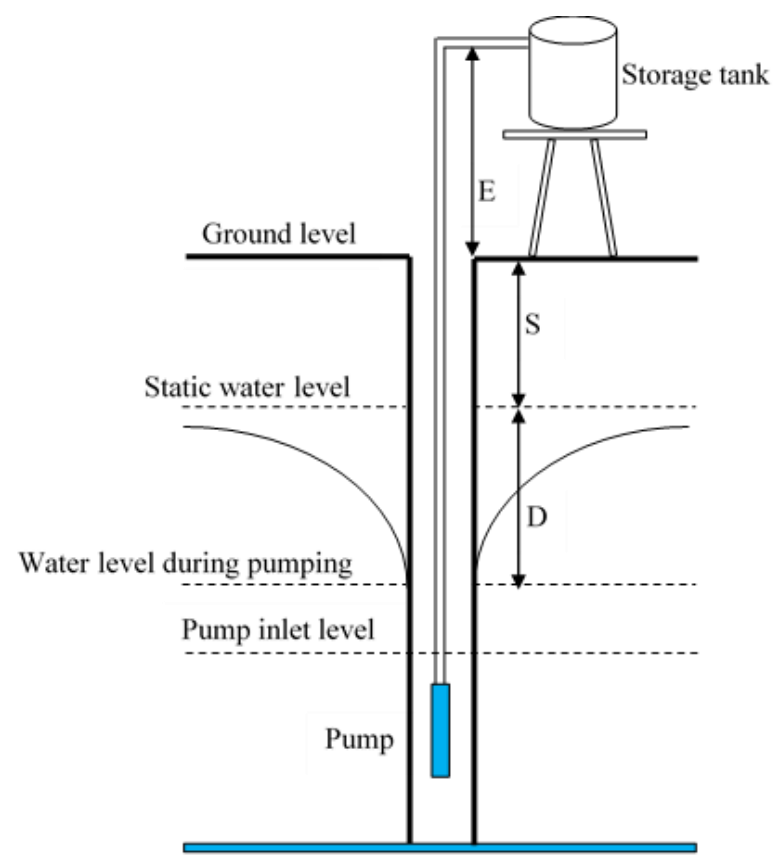

Figure 2. Water pumping system 
Total static head, $\mathrm{H}_{\mathrm{s}}=\mathrm{E}+\mathrm{S}+\mathrm{D}$

Total dynamic head, $\mathrm{H}_{\mathrm{d}}=\mathrm{E}+\mathrm{S}+\mathrm{D}+$ Friction loss in pipe and fitting.

$\mathrm{E}=6 \mathrm{~m}, \mathrm{~S}=4 \mathrm{~m}, \mathrm{D}=8 \mathrm{~m}$

The pipe friction loss depends upon the inside diameter of the pipe, the pipe length, the number bends in the pipe, and flow rate. Although the value of friction loss for each type of pipe size and fitting can be obtained from pipe sizing chart, for simplicity, $10 \%$ of total static head is usually added during design depending upon the type of pipe and fitting used in the system [11].

Thus,

Total static head, $\mathrm{H}_{\mathrm{s}}=6+4+8=18$

Total dynamic head, $\mathrm{H}_{\mathrm{d}}=6+4+8+(10 \%$ of 18$)$

$$
=19.8 \mathrm{~m} \approx 20 \mathrm{~m}
$$

\subsection{Water demand of the household}

A typical household size of 5 people and per capita water consumption of $120 \mathrm{~L} /$ person/day which is usually taken as the design standard for high income group in urban areas in Ghana was used to determine the waste demand of the household. Table 4 shows the water demand for the household.

Table 4. Water demand for the household

\begin{tabular}{lc}
\hline Item & Quantity \\
\hline $\begin{array}{l}\text { Total number of people in the } \\
\text { house (Average number of } \\
\text { family/household) }\end{array}$ & 5 \\
$\begin{array}{l}\text { Water consumption per person } \\
\text { per day in liter (L/day) }\end{array}$ & $120 \mathrm{~L} /$ day \\
$\begin{array}{l}\text { Total water requirement of the } \\
\text { household (120 L/person/day) }\end{array}$ & $600 \mathrm{~L} /$ day or 0.6 \\
$\begin{array}{l}\text { Storage day needed } \\
\text { (autonomy) }\end{array}$ & 3 \\
$\begin{array}{l}\text { Average peak sun hour of } \\
\text { Ghana (PSH) }\end{array}$ & $5 \mathrm{~h} /$ day \\
$\begin{array}{l}\text { Volume of water tank needed } \\
\text { for three-day storage }\end{array}$ & $1800 \mathrm{~L} / \mathrm{day} \mathrm{or} 1.8$ \\
Total dynamic head of well & $\mathrm{m}^{3} / \mathrm{day}, 0.36 \mathrm{~m}^{3} / \mathrm{h}$ \\
& $20 \mathrm{~m}$ \\
\hline
\end{tabular}

\subsection{Selection of pump}

The factors considered in the selection of pump for a particular work include: flow rate, head, power, efficiency, price, reliability, availability and ease of maintenance. The system was designed to pump 0.36 $\mathrm{m}^{3} / \mathrm{h}$ of water daily with a total dynamic head of $20 \mathrm{~m}$. Thus, Lorentz Helical Rotor PS200 HR-07 Solar Submersible Pump System was selected for the study with technical data shown in Table 5.
Table 5. Technical data Lorentz PS200 HR-07

\begin{tabular}{lc}
\hline Pump type & $\begin{array}{c}\text { Lorentz Helical } \\
\text { Rotor PS200 HR-07 }\end{array}$ \\
\hline Maximum head & $30 \mathrm{~m}$ \\
Maximum flow rate & $1.2 \mathrm{~m}^{3} / \mathrm{h}$ \\
Maximum efficiency & $61 \%$ \\
Nominal voltage (Solar & $24-48 \mathrm{~V} \mathrm{DC}$ \\
Operation) & \\
Motor current (Maximum) & $11 \mathrm{~A}$ \\
Nominal voltage (Battery & $24-48 \mathrm{~V} \mathrm{DC}$ \\
Operation) & \\
\hline
\end{tabular}

\subsection{Power required by motor-pump system}

The power required by the pump was obtained from pump curve in Figure 3.

From the pump curve, the power required by the pump is estimated at $48 \mathrm{~W}$.

The estimated power required was verified analytically as follows:

Pump efficiency, $\eta_{\mathrm{p}}$ is given by:

$$
\begin{aligned}
& \eta_{p}=\frac{\text { Power output delivered from the pump }}{\text { Power output delivered from motor to pump }} \\
& \eta_{p}=\frac{\rho g \mathrm{gH}_{\mathrm{d}}}{\mathrm{P}_{\mathrm{p}}} \\
& \mathrm{P}_{\mathrm{p}}=\frac{\rho \mathrm{gQH}_{\mathrm{d}}}{\eta_{\mathrm{p}}}
\end{aligned}
$$

Where,

$\rho=$ density of water

$\mathrm{g}=$ acceleration due to gravity

$\mathrm{P}_{\mathrm{p}}=$ Power output delivered from the motor to the pump $\mathrm{Q}=$ flow rate

The maximum efficiency of Lorentz PS200 HR-07 is 61 $\%$. Thus, the estimated pump efficiency was $35 \%$ at the flow rate of $0.36 \mathrm{~m}^{3} / \mathrm{h}$ at a head of $20 \mathrm{~m}$.

Motor efficiency, $\eta_{\mathrm{m}}=80 \%$,

$\mathrm{Q}=0.36 \mathrm{~m}^{3} / \mathrm{h}$,

$\mathrm{H}_{\mathrm{d}}=20 \mathrm{~m}$,

$\mathrm{g}=9.81 \mathrm{~m}^{2} / \mathrm{s}$,

$\rho=1000 \mathrm{~kg} / \mathrm{m}^{3}$.

$\mathrm{P}_{\mathrm{p}}=\frac{1000 \times 9.81 \times 0.36 \times 20}{0.35 \times 3600}=46.71 \mathrm{~W}$

This is close to the estimated value of $48 \mathrm{~W}$ obtained from the pump curve.

Motor efficiency, $\eta_{\mathrm{m}}$ is given by:

$$
\begin{aligned}
& \eta_{\mathrm{m}}=\frac{\mathrm{P}_{\mathrm{p}}}{\mathrm{P}_{\max }} \\
& \mathrm{P}_{\max }=\frac{\mathrm{P}_{\mathrm{p}}}{\eta_{\mathrm{m}}} \\
& \mathrm{P}_{\max }=\frac{46.71}{0.8}=58.4 \mathrm{~W} \approx 60 \mathrm{~W}
\end{aligned}
$$

Power input to the motor of $60 \mathrm{~W}$ was used. 


\subsection{Electrical demand of water supply system}

The electrical demand for the water supply system is shown in Table 6.

\subsection{Electrical demand of both electricity and water supply system}

The electrical demand of the system, for both electricity and water supply, is shown in Table 7. It was observed that the addition of the solar pump did not make any significant change in the energy demand.
Thus, the 6-kWh system designed for the household was enough for both electricity generation and water supply systems, bearing in mind that all the appliances would not be used at the same time.

\subsection{Selection of water tank}

The three days of autonomy used for the design and daily water demand of 600 litres required a polytank size of 1800 litres was selected.

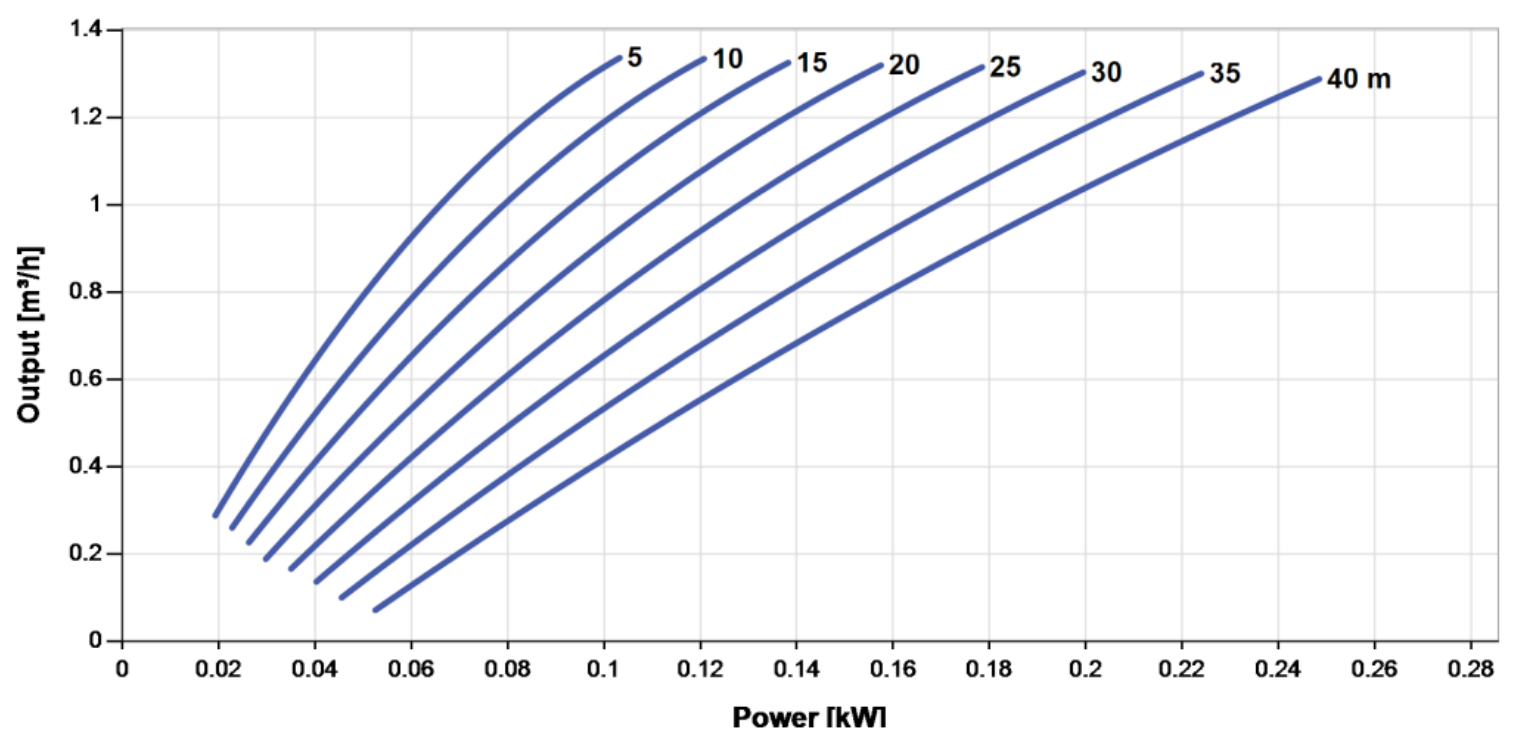

Figure 3. Pump curve for Lorentz PS200 HR-07

Table 6. Electrical demand for the water supply system

\begin{tabular}{lcccccccc}
\hline Appliance & Qty & $\begin{array}{c}\text { Load } \\
(\mathbf{W})\end{array}$ & $\begin{array}{c}\text { Total } \\
\text { load } \\
(\mathbf{k W})\end{array}$ & $\begin{array}{c}\text { Use/Day } \\
\text { (hours) }\end{array}$ & Efficiency & $\begin{array}{c}\text { Daily } \\
\text { load } \\
(\mathbf{k W h})\end{array}$ & $\begin{array}{c}\text { Oversize } \\
\text { factor }\end{array}$ & $\begin{array}{c}\text { Adjusted } \\
\text { daily load } \\
\text { (kWh) }\end{array}$ \\
\hline Solar Pump & 1 & 60 & 0.06 & 5 & 1.20 & 0.36 & 1.10 & 0.40 \\
\hline
\end{tabular}

Table 7. Electrical demand for the system for both electricity and water supply

\begin{tabular}{lcccc}
\hline Appliance & $\begin{array}{c}\text { Load } \\
(\mathbf{W})\end{array}$ & $\begin{array}{c}\text { Total load } \\
(\mathbf{k W})\end{array}$ & $\begin{array}{c}\text { Daily load } \\
(\mathbf{k W h})\end{array}$ & $\begin{array}{c}\text { Adjusted daily load } \\
(\mathbf{k W h})\end{array}$ \\
\hline All without pump & 5372 & 5.781 & 5.11 & 5.62 \\
Solar Pump & 60 & 0.06 & 0.36 & 0.40 \\
All with pump & 5432 & 5.841 & 5.47 & 6.01 \\
\hline
\end{tabular}




\subsection{Layout of the solar PV system for both electricity and water supply}

The connection layout of the solar PV system is shown in Figure 4. The solar PV system consists of the array, charge controller, batteries and the inverter. The PV array generates electrical power for the entire PV system. It consists of PV modules connected in series and parallel combinations so that the resulting voltage and current are compatible with the charge controller and the requirements of the loads. The PV modules are made of solar cells which convert solar radiation into direct current (DC) electricity which is stored in the battery banks. The charge controller regulates the power from the PV array to prevent the batteries from overcharging. The DC loads take power directly from the battery. However, the DC electricity has to be converted to alternating current (AC) electricity via the inverter so that the AC loads could be used.

\subsection{Estimated cost of components for both electricity and water supply system}

The cost of components used for the system for both electricity and water supply are shown in Table 8.

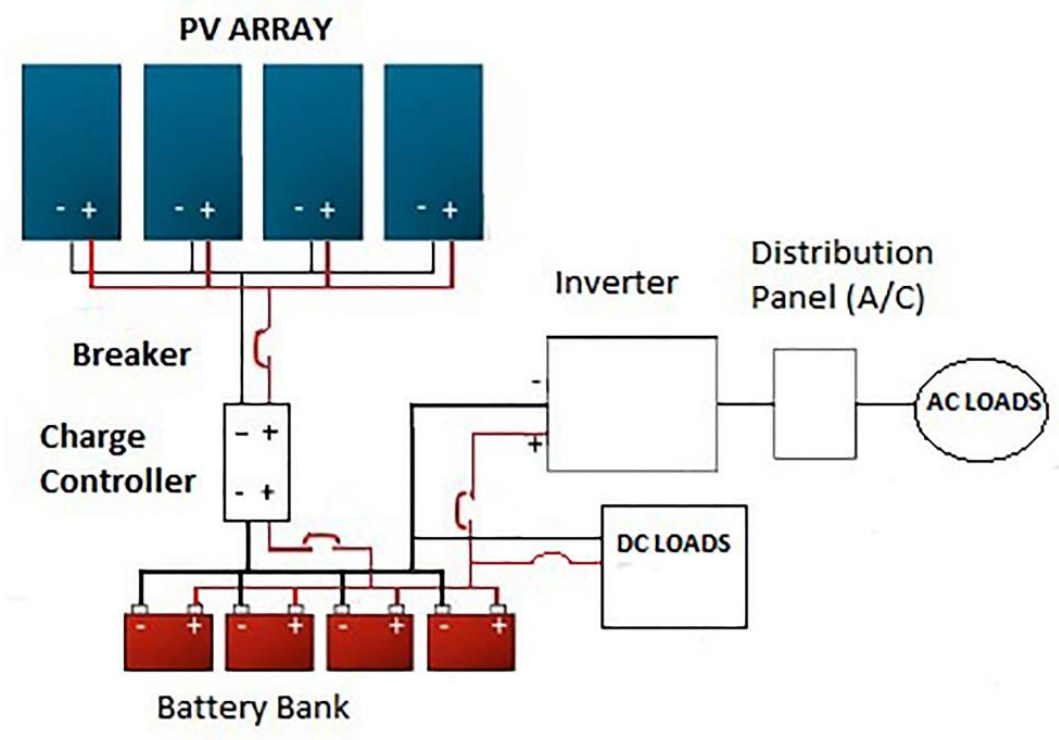

Figure 4. Connection layout of the solar PV system

Table 8. Cost estimate of components for both electricity and water supply system

\begin{tabular}{lccc}
\hline Item/Description & Quantity & Unit Price (\$) & Total (\$) \\
\hline Water pumping system & & & 1800 \\
Lorentz Helical Rotor PS200 HR-04 Submersible Solar Pump System & 1 & 1 & 350 \\
Construction of well & 1 & 200 & 200 \\
Polytank & 1 & 100 & 100 \\
Polytank structure & 1 & 20 & 20 \\
PVC pipe & & 2470 \\
Subtotal (Water pumping system) (A) & & 7950 \\
Subtotal (Electricity generation system without water supply) (B) & & 10420 \\
Total (Electricity generation system with water supply) (A+B) & & & \\
\hline
\end{tabular}




\subsection{Simple payback analysis for both electricity and water supply system}

The same project lifetime of 25 years was used to estimate the lifetime cost of the project.

$\mathrm{O} \& \mathrm{M}$ cost of water system $=10 \%$ of water system cost $\mathrm{O} \& \mathrm{M} \cos \mathrm{t}=0.1 \times \$ 2470=\$ 247$

Over the period of 25 years, the pump may be replaced 2 times using the warranty period of 10years. Therefore, Pump replacement cost, $C_{P}=2 \times$ initial cost of pump $\mathrm{C}_{\mathrm{P}}=2 \times \mathrm{US} \$ 1800=\mathrm{US} \$ 3600$

Total lifecycle cost of system, $\mathrm{T}_{\mathrm{w}}$ is given by:

$\mathrm{T}_{\mathrm{w}}=$ System cost $+\mathrm{O} \& \mathrm{M} \operatorname{cost}+\mathrm{C}_{\mathrm{p}}$

$=2470+247+3600=$ US $\$ 6317$

Estimate of annual water pumped, $\mathrm{W}_{\mathrm{A}}$ is given by: $\mathrm{W}_{\mathrm{A}}=$ Water pumped per day $\mathrm{x} 365$ days in a year $=600 \mathrm{~L}$ x $365=219000 \mathrm{~L}$

Water pumped during 25 years, $\mathrm{W}_{\mathrm{T}}$ is given by:

$\mathrm{W}_{\mathrm{T}}=\mathrm{WA} \times 25$ years

$=219000 \mathrm{~L} \times 25=5475000 \mathrm{~L}$

Water cost $(\mathrm{US} \$ / \mathrm{L})=\frac{T_{W}}{W_{T}}$

$=\frac{\mathrm{US} \$ 6317}{5475000}=\mathrm{US} \$ 0.001154 / \mathrm{L}$

Net annual cash inflow from the water system, $\mathrm{N}_{\mathrm{W}}$ is given by: $\mathrm{N}_{\mathrm{W}}=\mathrm{W}_{\mathrm{T}} \mathrm{x}$ Water cost

$=219000 \mathrm{~L} \times \mathrm{US} \$ 0.001154 / \mathrm{L}=\mathrm{US} \$ 252.726$

Simple Payback Period, SPP is given by:

SPP $=\frac{\text { Total installed cost for electricity and water }- \text { Incentive }}{\left(\mathrm{N}_{E}+\mathrm{N}_{W}\right)}$

$=\frac{10420-0}{(541.95+252.726)}=13.1$

Simple payback period $=13$ years

\section{Results and Discussion}

The electrical demand for the PV system for electricity supply to the household without water system shown in Table 1 was estimated at $6 \mathrm{kWh}$ per day and this load was expected to remain constant throughout the year. The system voltage was $48 \mathrm{~V}$ and the maximum depth of discharge for the battery taken to be $80 \%$ with efficiency of $85 \%$. The three days of autonomy was used for the design required a Standard Battery Capacity of $600 \mathrm{Ah}$ and thus, Victron GEL $\mathrm{OPzV}$ batteries $2 \mathrm{~V}, 600 \mathrm{Ah}, \mathrm{C} 10$ was selected. A total number of 24 batteries was needed with 24 batteries connected in series and 1 in parallel. The battery storage was design to meet the peak demand of the household and still be able to supply power during three days of autonomous; where the load demand would be met solely by the storage system. The average peak sun hour per day was 5 hours, and battery efficiency was $85 \%$. Thus, the total required output power from array was $1.41 \mathrm{kWp}$ with peak value of $2.56 \mathrm{kWp}$ and thus, the total output current from the PV array was 29.37 A. A total of 8 modules of BlueSolar 320 W $24 \quad \mathrm{~V}$ Polycrystalline Solar Module with specifications shown in Table 2 were selected with 2 modules connected in series and 4 in parallel. In order to reduce dust accumulation, ensure effective cleaning by rainfall and receive adequate sunlight, a tilt angle of $30^{\circ}$ facing south was chosen for the PV array. The array to inverter ratio was 1.1 , power factor was 0.8 and rated power of the inverter owas $2.91 \mathrm{kVA}$. Thus, one of Phoenix Inverter $48 / 3000$ inverter was selected. The total current through the controller was found to be 47.2 A and thus, one piece of Victron BlueSolar MPPT 150/45-Tr Controller was selected.

The total cost of the project to supply electricity was estimated at $\$ 7950$ as shown in Table 3. The project lifetime was estimated at 25 years which is the warranty period of the solar PV modules. The battery has warranty period of 10 years and thus, the batteries are expected to be replaced 2 time during the project life. The present prevailing industry rates for operation and maintenance cost of $10 \%$ of system cost brings the total lifecycle cost of system to US\$13545. The total energy to be generated during the 25 years was estimated at $116800 \mathrm{kWh}$ which resulted in energy cost of US\$0.116/kWh. The net annual cash inflow from the system was US\$541.95 given a Simple Payback Period of 15 years. This means the system meant to supply electricity to the household without water supply would be able to pay for itself before the project life of 25 years.

The water supply system was designed to pump 0.36 $\mathrm{m}^{3} / \mathrm{h}$ of water daily with a total dynamic head of $20 \mathrm{~m}$ as shown in Table 4. Thus, Lorentz Helical Rotor PS200 HR-07 Solar Submersible Pump System with specifications in Table 5 was selected to deliver this quantity of water daily. The power required to pump water to the household was estimated at $60 \mathrm{~W}$. It was found from Table 6 that the addition of the solar water pump to the system designed to supply electricity did not make any significant change in the electrical demand of the household. Thus, the 6-kWh system designed for the household was enough to supply both electricity and water to the household throughout the year, bearing in mind that all the appliances would not be used at the same time. The daily water demand of 600 litres and the three days of autonomy necessitated a storage facility and thus, a polytank size of 1800 litres was selected. 
The project lifetime and the pump warranty period are 25 years and 10 years respectively. Thus. the pump would be replaced 2 time during the project life. The operation and maintenance cost was estimated at $10 \%$ of system cost which brings the total lifecycle cost of the system to US\$6317. Thus, the water pumped during the 25 years was $5475000 \mathrm{~L}$, water cost was US\$0.001154/L and net annual cash inflow from the system of US $\$ 252.726$. The total installed cost for both electricity and water supply systems were estimated at US $\$ 10420$ as shown in Table 8. The net annual cash inflow from the energy system and the water system were US\$541.95 and US\$252.726 respectively. This gave a Simple Payback Period of 13 years which means that the system to supply both electricity and water to the household would be able to pay for itself before the project life of 25 years. The addition of the water supply to the electricity supply system reduced the payback period by 2 years. Thus, the system for both electricity supply and water supply was more economical than the system which supplies electricity without water supply.

\section{Recommendations}

It is recommended that the results of this study should be implemented in other large cities of Ghana and other developing countries, with similar socioeconomic and climatic conditions, where electricity and water supply in peri-urban areas are major challenges.

Further study should be conducted to ascertain the technical and economic feasibility of PV systems for electricity and water supply in slums areas.

\section{Conclusion}

The study conducted technical and economic feasibility analysis of solar PV system for both electricity and water supply for a single household in newly developing peri-urban areas which accommodate people who are mostly in the high-income bracket in developing countries with Kumasi, Ghana as case study, using Simple Payback Analysis. The system was found to be technically and economically feasible. The payback period of solar PV system for electricity supply without water supply was found to be 15 years and the addition of the water supply to the system reduced the payback period to 13 years. This means that the addition of the water supply to the electricity supply system reduced the payback period by 2 years. Thus, the system meant to supply both electricity and water to the household would be able to pay for itself before the project life of 25 years. Hence, PV systems are technically and economically feasible for electricity and water supply for single households in newly developing high-income peri-urban areas in Kumasi, Ghana and could also be implemented in other developing countries with similar socio-economic and climatic conditions.

\section{References}

[1] IRENA, Renewable Power Generation Costs in 2014. IRENA, Bonn.https://www.irena.org/document downloads/publications/irena_re_power_costs_2014_report.p df, 2015 (Access date: 10 January, 2019).

[2] WHO, Key facts from Joint Monitoring Programme (JMP), 2015 report. https://www.who.int/water _sanitation_health/monitoring/jmp-2015-key-facts/en/, 2016 (Accessed date: 10 January, 2019).

[3] C. Nauges and D. Whittington, "Estimation of water demand in developing countries: An overview". World Bank Res. Obs. 25(2) (2010) pp. 263- 294.

[4] C. Morinville, Beyond the pipe: Participation and alternative water provision in underserved areas of Accra, Ghana:, in Institute for Resources, Environment and Sustainability. 2012, The University of British Columbia: Vancouver, Canada.

[5] R. Hiremath, S. Shikha and N. Ravindranath, "Decentralized energy planning, modelling and application". Renewable and sustainable energy review. 11(5) (2007) pp. 729-758.

[6] P. Purohit and A. Michaelowa, "CDM potential of SPV pumps in India". Renewable and Sustainable Energy Reviews. 12 (2008) pp. 181-199.

[7] S.S. Chandel, N.M. Nagaraju and R. Chandel, "Review of solar photovoltaic water pumping system technology for irrigation and community drinking water supplies". Renewable and Sustainable Energy Reviews. 49 (2015) pp. 1084-1099.

[8] R. Foster and A. Cota, Solar water pumping advances and comparative economics. Energy Procedia 57.2013 ISES Solar World Congress, www.sciencedirect.com, 2013 (Access date: 13 January, 2019).

[9] A.A. Nafeh, "Design and Economic Analysis of a Standalone PV System to Electrify a Remote Area Household in Egypt". Renewable Energy J. 2 (2009) pp. 33-37.

[10] P. Birajdar, S. Bammani, A. Shete, A. R. Bhandari and S. Metan, "Assessing the Technical and Economic Feasibility of a StandAlone PV System for Rural Electrification: A Case Study". International Journal of Engineering Research and Applications (IJERA). 3(4) (2013) pp. 2525-2529.

[11] Z. Girma, "Techno-economic analysis of photovoltaic pumping system for rural water supply in Ethiopia". International Journal of Sustainable Energy. 36(3) (2017) pp. 277-295. 
[12] O.M. Abdeen, "Solar water pumping clean water for Sudan rural areas". Renew Energy. 24 (2001) pp. 245-258.

[13] S. Bhakta and V. Mukherjee, "Performance indices evaluation and techno economic analysis of photovoltaic power plant for the application of isolated India's island". Sustainable Energy Technologies and Assessments. 20 (2017) pp. 9-24.

[14] H.A. Kazem, M.H. Albadi, A.H.A. Al-Waeli, A.H. AlBusaidi,and M.T. Chaichan, "Techno-economic feasibility analysis of $1 \mathrm{MW}$ photovoltaic grid connected system in Oman". Case Studies in Thermal Engineering. 10 (2017) pp. 131-141.

[15] A.A. Imam, Y.A. Al-Turki, and S.R. Kumar, "TechnoEconomic Feasibility Assessment of Grid-Connected PV Systems for Residential Buildings in Saudi Arabia - A Case Study". Sustainability. $12 \quad(2020) \quad$ pp. 262; doi:10.3390/su12010262.

[16] B. Yaniktepe, O. Kara, and C. Ozalp, "Technoeconomic Evaluation for an Installed Small-Scale Photovoltaic Power Plant". International Journal of Photoenergy. 1 (2017) pp. 1-7. https://doi.org/10.1155/2017/3237543.

[17] S. Lal, P. Kumar, and R. Rajora, "Techno-Economic Analysis of Solar Photovoltaic Based Submersible Water Pumping System for Rural Areas of an Indian State Rajasthan". Science Journal of Energy Engineering. 1(1) (2013) pp. 1-4. doi:10.11648/j.sjee.20130101.11.

[18] A. Singh, Techno- economic feasibility study of solar water pumping for public facilities in Nigeria. Humboldt State University: https://digitalcommons.humboldt.edu/etd/322, 2019 (Access date: 25 February, 2021).

[19] Ghana Statistical Service, 2010 Population and Housing Census, in Summary Report of Final Results. 2012, Ghana Statistical Service: Accra, Ghana.

[20] WHO/ UNICEF, Progress on Drinking Water, Sanitation and Hygiene: 2017 Update and SDG Baselines, in Joint Monitoring Programme (JMP) report July 2017. 2017, WHO/ UNICEF: Geneva.

[21] S.E. Owusu and P.K.B. Asamoah, "Servicing land for housing development in periurban areas of Kumasi, Ghana: theory versus practice". Journal of Science and Technology. 25(1) (2005) pp. 77-85.

[22] NASA, NASA Surface meteorology and Solar Energy Location 2018. https://catalog.data.gov/dataset/surface-mete orology-and-solar-energy, 2018. (Access date: 12 April, 2019).

[23] Solar Panels Photovoltaic, Power consumption of 101+ typical household appliances. Solar Panels Photovoltaic. http://solarpanelsphotovoltaic.net/power-consumption-101typical-household-appliances/, 2013 (Access date: 12 February, 2019).
[24] H.A. Guda and U.O. Aliyu, "Design of a Stand-Alone Photovoltaic System for a Residence in Bauchi". International Journal of Engineering and Technology. 5(1) (2015) pp. 3444.

[25] J.D. Mondol, Y.G. Yohanis and B. Norton, Optimal Sizing of Array and Inverter for Grid-connected Photovotaic Systems. Solar Energy. 80(12) (2006) pp. 1517-1539. 